\title{
Comparing the effectiveness of schema therapy and CBT On modifying maladaptive schemas in patients 16 to 23 years Bulimia nervosa considering the parental bonding
}

\author{
Tahereh Mahmoudiyandastnaee ${ }^{1}$, Sholeh Amiri², Hamidtaher Neshatdoost ${ }^{3}$, Gholamreza \\ Manshaei $^{4}$ \\ 1-Assistant Professor, Department of Psychology, Islamic Azad University, Behshahr Branch, Behshahr, Iran \\ (Corresponding Author). ORCID: 0000-0002-6833-6462Ｅ-mail: Mahmodian.mina@yahoo.com \\ 2- Professor, Department of Psychology, University of Isfahan, Isfahan, Iran. ORCID: 0000-0002-9906-5802 \\ 3- Professor, Department of Psychology, University of Isfahan, Isfahan, Iran. ORCID: 0000-0001-6368-0769 \\ 4- Associate Professor, Department of Psychology, Islamic Azad University,Isfahan (Khorasgan) Branch, \\ Isfahan, Iran. ORCID: 0000-0002-9486-9713
}

Received: $14 / 11 / 2018$

Accepted: 20/02/2019

\begin{abstract}
Introduction: According to the World Health Organization eating disorder is one of the most challenging diseases of adolescents with a developing prevalence.

Aim: The present study was aimed at comparing the effect of schema therapy and CBT on modifying early maladaptive schemas in patients with bulimia nervosa considering parental bonding.

Method: The study had an experimental method was used in this study with pretest-posttest design and followed-up with control group. The study population included all patients from 16 to 23 years of age with eating disorders who had referred to psychiatry centers of in Tehran. Purposive sampling was used in this study in which, by performing psychological screening, 39 patients were diagnosed to have Bulimia nervosa. Finally, the selected patients were matched in two experimental groups and one control group. The data was collected through two questionnaires (Parental Bonding Questionnaire and Young Schema) and diagnostic interviews based on diagnostic criteria for eating disorders and psychiatric diagnosis.
\end{abstract}

Results: The main problems of the patients included having cuts, being rejected, autonomy, and impaired performance. However, they were less vulnerable in other areas including orientation and violating restrictions.

Conclusion: The findings of this study can be helpful in the etiology of bulimia nervosa disorder based on the systematic approach and pave the way for further research in this area.

Keywords: Schema therapy, CBT, Bulimia nervosa, Early maladaptive schemas, Parental bonding 


\section{مقايسه اثربخشى طر حواره در مانى و درمان شناختى رفتارى بر تعديل طر حواره هاى ناساز

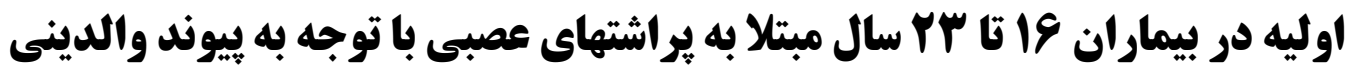

طاهره محموديان دستنايى'، شعله اميرى '، حميد طاهر نشاط دوست'، غلامرضا منشئى

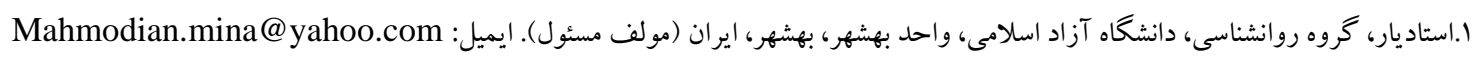

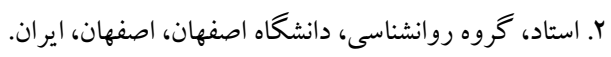
r. استاد، كروه روانشناسى، دانشكاه اصفهان، اصفهان، ايران.

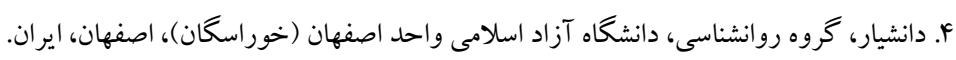

مقدمه: برطبق گزارش سازمان جهانى بهداشت، اختلال خوردن از جالش برانكيز ترين بيمارى هاى دوران نوجوانى با شيوع رو به كسترش است.

هدف: مطالعه حاضر مقايسه اثربخشى طرحواره درمانى و درمان شناختى رفتارى بر بهبود طرحواره هاى ناساز گار اوليه در بيماران

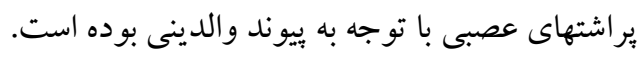

روش: آزمايشى با طرح بيش آزمون- بِ آزمون ، ييڤيرى با گروه كنترل مى باشد. جامعه آمارى شامل بيماران داراى اختلال

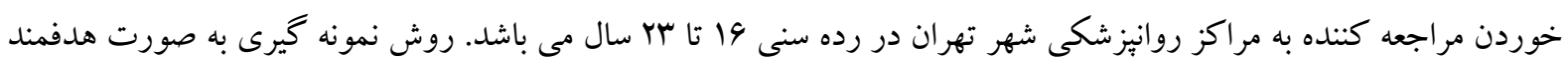

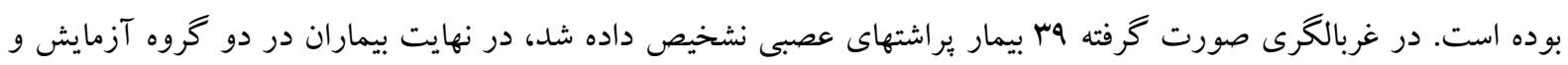

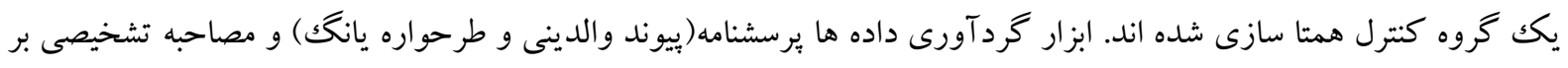

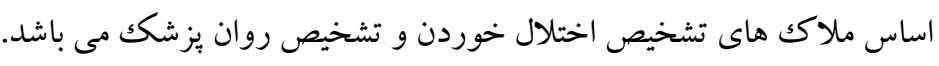

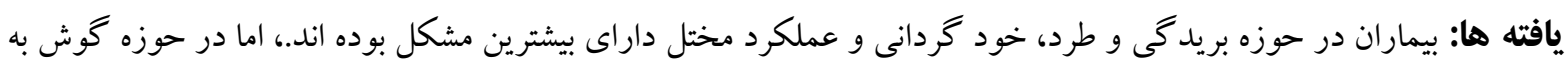

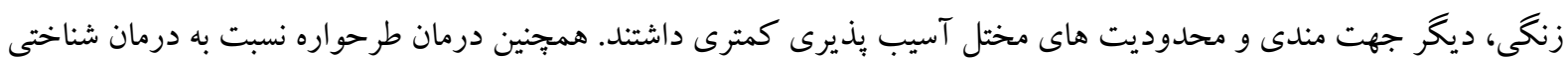

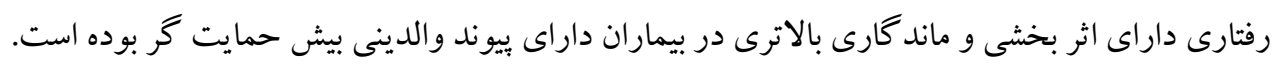
نتيجه كيرى: يافته هاى بدست آمده از يُزوهش مى تواند در سبب شناسى اختلال يراشتهايى عصبى مبتنى بر نقش خانواده در اين اختلال مهر تاييد بزنيم. كليد وازه ها: طرحواره درمانى، درمان شناختى رفتارى، براشتهايى عصبى ، بيوند والدينى 
افراد تحت شرايط مشابه خواهد خورد. مبتلايان به اين

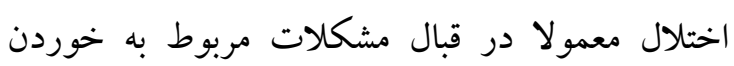
احساس شرمندگى مى كنند و درصدد ينهان ساختن

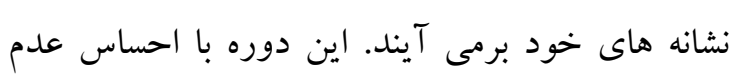

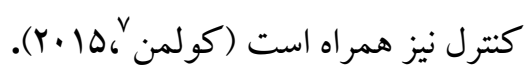
اختلال خوردن داراى سبب شناسى جند فير فاكتورى است. عوامل متعدد زيست شناختى، روانشناختى، روان

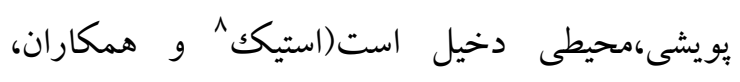

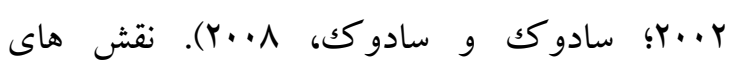
خانوادگى يا الكوهاى تثبيت شده رفتار براى انجام

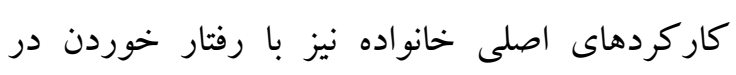

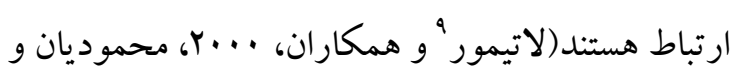
همكاران ، Iraf،). شيوه هاى رزيم غذايى كود كان، فعاليت هاى جسمى، رضايتمندى بدنى به وسيله والدين

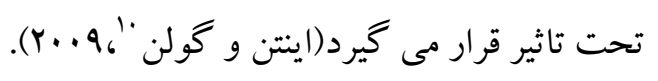

برخى يُزوهش ها نشان داده اند مراقبت هاى

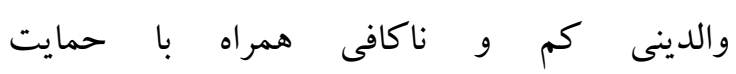

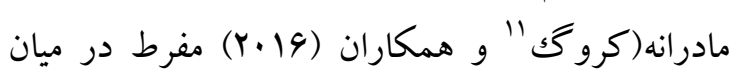

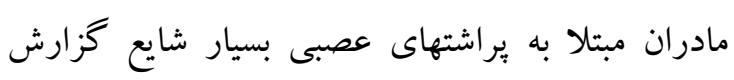

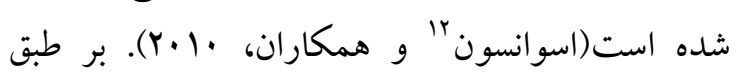
يثزوهش هاى ياركر سهم والدينى در فضاى بيوند كودكك -والد مورد غفلت واقع شده و يا در بهترين حالت فقط در تئورى دلبستخى لحاظ شده است. در

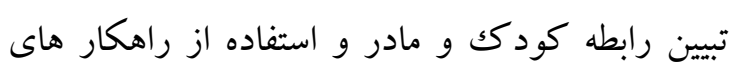
ناساز گار بوسيله كودك (مانند اختلال خوردن) يانگك

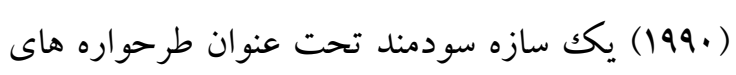
ناساز گار اوليه مطرح كرد. او بيان داشت كه طرحواره هاى ناساز كار اوليه، نتيجه تجارب بين فردى منفى الى بيان

\footnotetext{
7. Colman,A.M

SticeE

9 . Lattimore,P.J.

10 . Enten, R. S., \& Golan, M.

11 . Krug, I.

12. Swanson $\mathrm{H}$
}

اختلالات خوردن يكى از اختلالات روانى به شمار مى مقى رود كه آمار مرگك و مير ناشى از آن بسيار بالا

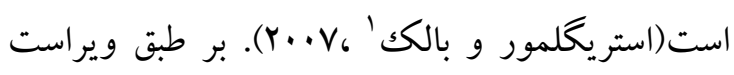

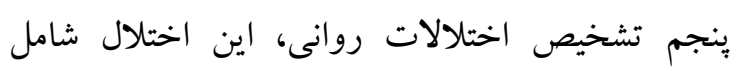

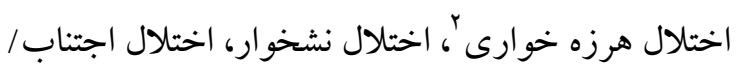

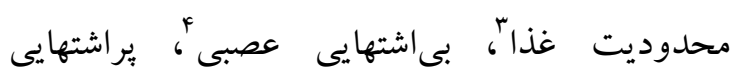

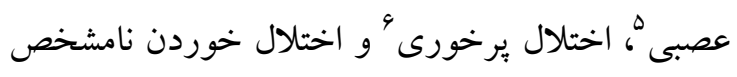

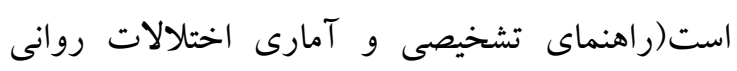

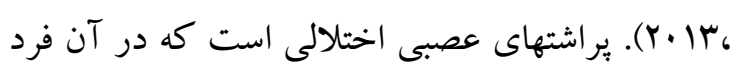
از افزايش وزن مى ترسد و درباره اندام خود تصورات

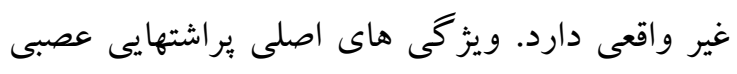
شامل خوردن با ولع و روش هاى جبرانى نامناسب براى

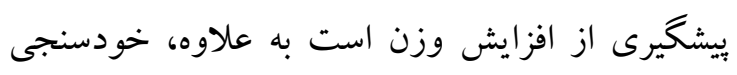
فرد مبتلا به شدت تحت تأثير شكل و وزن بدن قرار

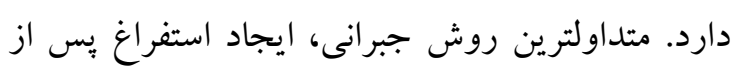

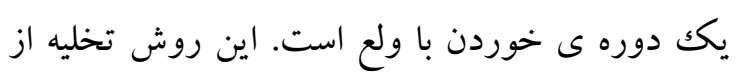

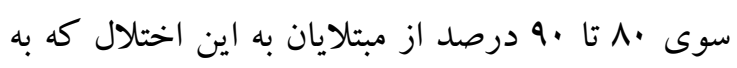

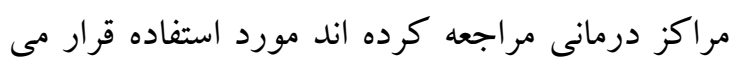
كرفت. ساير رفتارهاى تخليه اى شامل: مصرف نابجاى

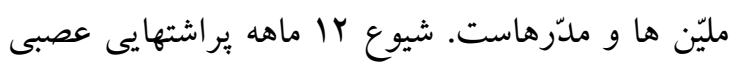

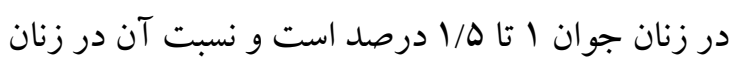
نسبت به مردان بالاتر است. (انجمن روانيز شكى امريكا،

.$(Y \cdot 1)$ براى تأييد اين تشخيص، خوردن با ولع و رفتارهاى جبرانى نامناسب بايد بطور متوسط دست كم دوبار در

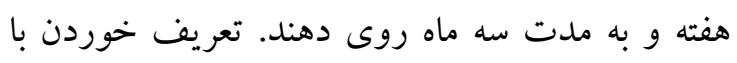
ولع عبارت است از خوردن ميزانى از غذا در يكك دوره ى زمانى مشخص، بيش از آن جيزى است كه بيشتر

\footnotetext{
. Striegel-Moore,R.H,\& Bulik,

pica(pronunciation: pay-kaa)

avoidant restrictive food intake disorder(ARFID)

. anorexia Nevosa

5 . bulimia Nevosa

6 . binge eating
} 
نرمال يرداختند. در اين يُزوهش دختران نوجوان داراى وزن بالا، درمقايسه با دختران داراى وزن نرمال ،

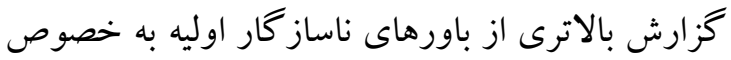
نوع شرم/ نقص داشتند. همجنين در نتايج بزوهش بون،

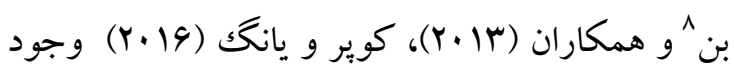
طرحواره هاى ناساز گار اوليه در افراد براشتهايى عصبى ونى ت ت تاييد كرديد.

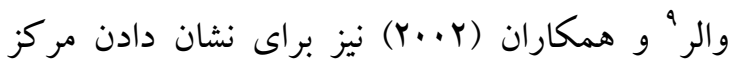
شناخت هاى آسيب شناسى برخورى از مفهوم باورهاى مركزى استفاده كرده اند، عموما فرض شده است كه باورهاى ناساز گار اوليه به استقلال و عملكرد آسيب ديده مربوط است كه سبب آسيب يذيرى شناختى در روابط والد- كودك مى شود، كه اين خود سبب افزايش ادراك مشكلات تغذيه در دريافت روابط نامناسب و تقويت باورهاى ناساز كار اوليه مى شود. در واقع عملكرد مختل خانواده با آسيب شناسى روانى اختلال هاى خوردن ارتباط دارد و در اين رابطه، باورهايى را كه روان بنه ها را فعال مى كند به عنوان ميانجى مطرح مى شوند. مثلاً روان بنه ى شرم به عنوان يكك ميانجى در رابطه ن ناكار آمدى خانواده و آسيب شناسى خوردن مى باشد. ناكار آمدى خانواده به عنوان

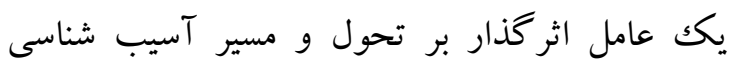
رواين خرخورى مى باشد (استروبر و هامفرى، 19AV). ماسن و همكارانش (1919) بيشنهاد مى دهد كه اين

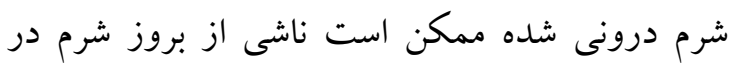

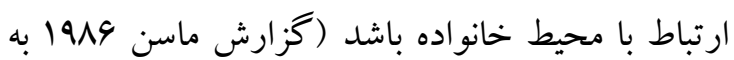
نقل از پاتريس هـ·r). وقتى روابط بيوند والدينى با نشانه هاى اختلال خوردن مورد بررسى قرار مى گيرد، باورها ناساز گار هسته اي هستند كه نقش ميانجى را در اين رابطه ايفا مى كنند و جهت بررسى و اثر روابط

\footnotetext{
8 . Boone, $\mathrm{L}$

9 . Waller, G
}

نخستين سال هاى زندگى در درون و بيرون خانواده است (يانگك، •199). در مورد اختلالات مربوط به غذا دئا خوردن، بيان شده كه تجارب زود هنكام منفى و آسيب زا منجر به تشكيل الخوهاى ناساز گارانه مى شود

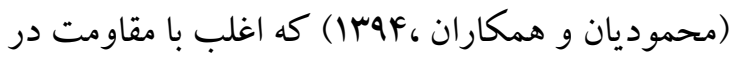
برابر تغيير گره خورده است. به عنوان مثال كودكى كه هـ مراقبت مادرانه كمى دريافت مى كند ممكن است نتيجه بخيرد به اين دليل است كه او ذاتا داراى نقص و ودئ

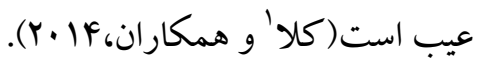

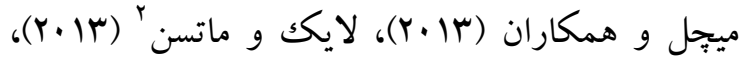

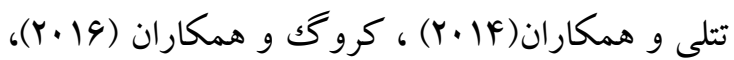

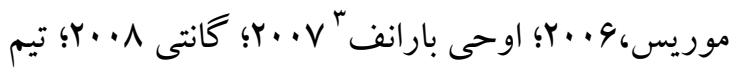
تيم • · · r در بثزوهش هاى خود ارتباط بين تأثير والدين

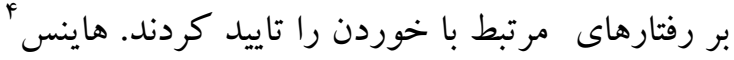

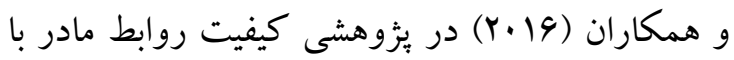
كودك رادر اختلال خوردن تاييد قرار داده اند. در خصوص نقش باور هاى هسته اى و طرحواره ها در توسعه و تداوم اختلال :يراشتهايى عصبى تاكيدات

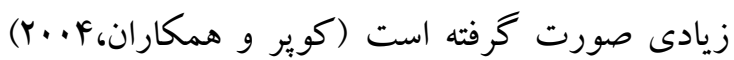
اين باورها كه از تجارب اوليه و يا در مراحل بعدى

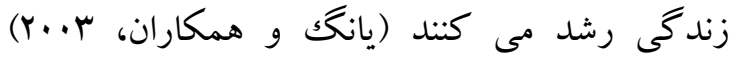
ممكن است در حوزه هاى متفاوتى وجود داشته باشند، اما باورهايى كه مربوط به خود هستند، اغلب فرض شده نقش تعيين كننده اى در آسيب شناسى روانىه

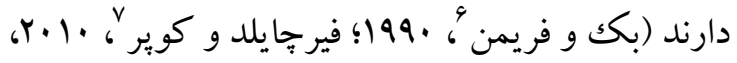

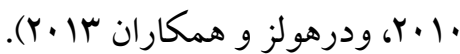
شايقيان و همكاران (•وrا) در بزوهشى به بررسى طرحوارهها و ييوند والدينى در دختران نوجوان جاق و

\footnotetext{
. Cella

2. Lyke Jennifer; Masten Julie.

. Oei, T. P., \& Baranoff, J.

. Haines, J.

5 . Psychopatology

${ }^{6}$. Beck, A. T., \& Freeman, A.

. Fairchild, H., \& Cooper, M
} 
است، متمركز باشد. با توجه به نقش شناخت در اختلالات خوردن شناسايى باورهاى هسته اى و طرحواره هاى شناختى از مفاهيم قابل بحث مى باشد. بر همين اساس باتوجه به مطالعات انجام شده و نظريه هاى مطرح شده اثر بخشى طرحواره درمانى و درمان شناختى رفتارى بر تعديل طرحواره هاى ناساز گار اوليه مورد بررسى قرار گرفت لذا يزوهش حاضر به دنبال ״ياسخ به اين سوال است كه آيا بكار گيرى طرحواره درمانى بر تعديل طرحواره هاى ناساز گار اوليه شكل

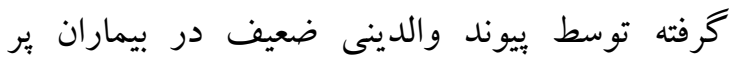
اشتهاى عصبى اثربخش است؟ درمان شناختى و رفتارى جطور؟ آيا بين اثربخشى اين دو روش درمانى با توجه به بيوند ضعيف والدينى تفاوت وجود دارد؟

\section{روش}

روش بثزوهش حاضر به صورت آزمايشى با طرح بيش

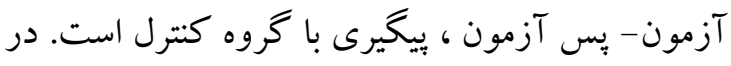
اين طرح بيش از مداخله بيش آزمون براى آزمودنى ها اجرا گرديد كه طرحواره هاى ناساز گار بيماران

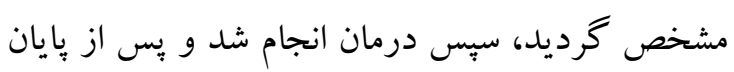

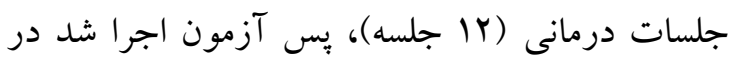

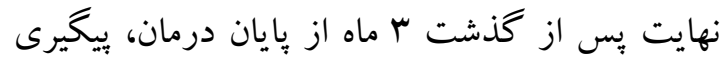

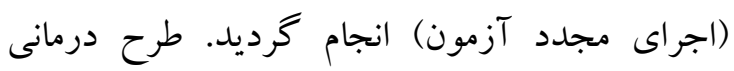
استفاده شده براى طرحواره درمانى الكويى بركرفته از

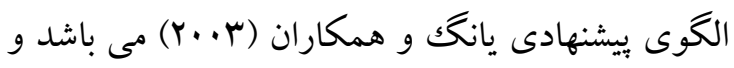
طرح درمان شناختى رفتارى براى اختلال خوردن

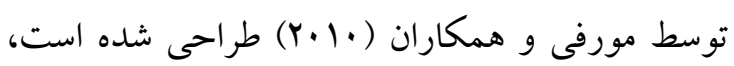
كه در اين مطالعه از تركيب بروتكل طراحى شده مورفى و همكاران و تكنيك هاى شناختى و رفتارى

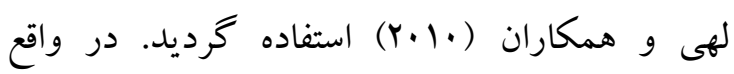
يروتكل درمانى اختلال خوردن شبيه به برتكل درمانى بيماران اضطرابى است (فايربون، كوير و سفران و و
والدى بر اختلال هاى خوردن بايد باورهاى هسته اى

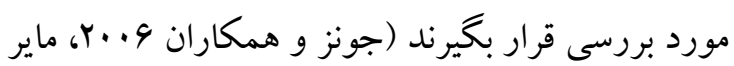

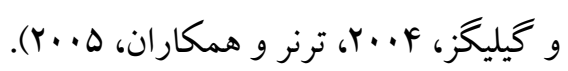
بر اساس تئورى الكويى ييشنهاد شده توسط يانگك ونك

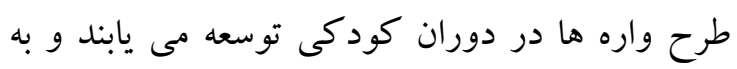
صورت قالب هايى براى بردازش تجارب بعدى به كار

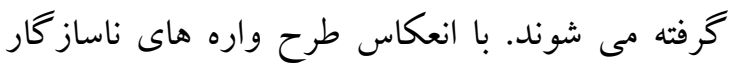
اغلب باورهاى بى قيد و شرطى درباره خود شخص

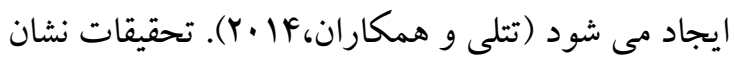

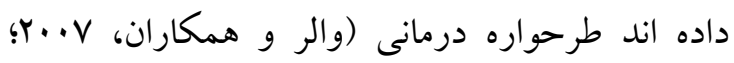

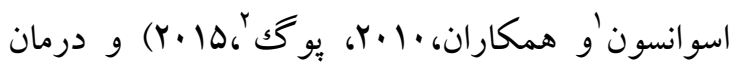

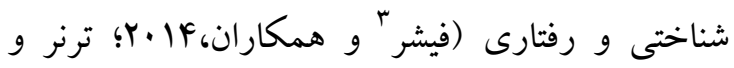

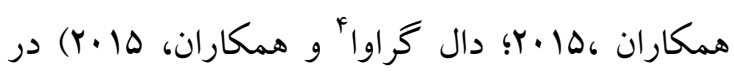
كاهش علائم اختلال خوردن نقش بسزايى دارد.

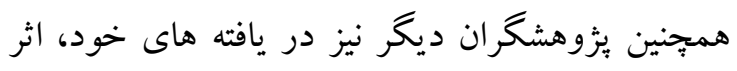
بخشى درمان متمركز بر طرحواره را، در كاهش نشانه هاى مرضى اختلالات خوردن تاييد كرده اند (سكروه دره

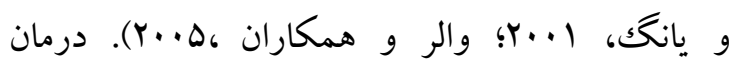
اختلالات خوردن يك جالش قابل توجه و كار با اين جمعيت بسيار دشوار است، بررسى ادبيات درمانى

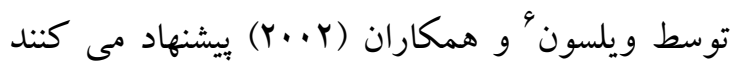
درمان شناختى و رفتارى براى بيماران براشتهاى روانى

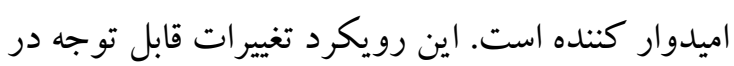
رفتار خوردن، باكسازى، و نخگش هاى غير طبيعى در مورد شكل بدن و وزن نشان داده است و نسبت به ساير درمان ها موثرتر است. اما در دراز مدت نياز به بيى - مورد كيرى دارد. اين مسئله نشان مى دهد كه درمانكر بايد بر

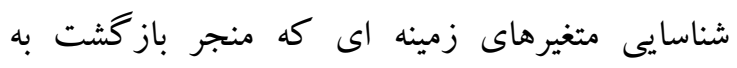

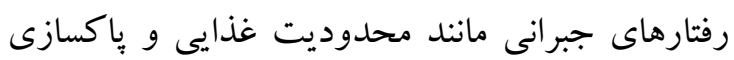

\footnotetext{
. Swanson, $\mathrm{H}$.

. Pugh, M.

3. Fischer, $\mathrm{S}$

4 . Dalle Grave, R.

5. Cecero, J. J., \& Young, J. E.

6 . Wilson
} 
(داراى اختلال خوردن با توجه به DSM-V مى باشند، و محدوده سنى براى آنها 19 الى بـ سالى سال است) و معيارخروجى مطالعه شامل بيمارانى بوده است كه (داراى ساير اختلالات روانيزشكى همراه با اختلال خوردن، سن بالاتر از بr سال بوده اند). در گروه آزمايش اول مداخله طرحواره درمانى ، در خروه بره

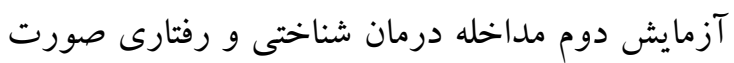

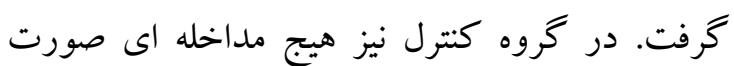

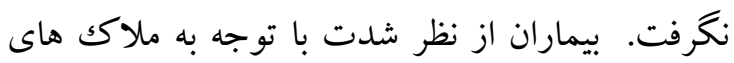
تشخيص و طبقه بندى اختلالات روانى ويراست بنجم در كروه خفيف (به طور متوسط ب-1 دوره رفتار جبرانى نامناسب در هفته) قرار داشتند.

ابزار ابزار كردآورى داده ها برسشنامه و مصاحبه تشخيصى بر اساس ملاكك هاى تشخيص اختلال بى اشتهايى روانى مبتنى بر (DSM-5) و تشخيص روان بز شكك مى

باشد. در اين يزوهش از دو برسشنامه استفاده خرديد:

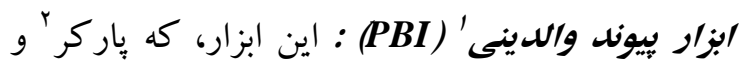
همكاران در سال 19V9 ساختند، سبك هاى بيوند والدينى را مى سنجد. اين مقياس، ابزارى كذشته نخر

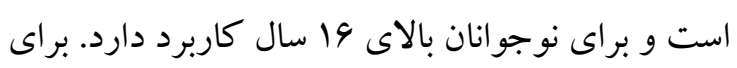

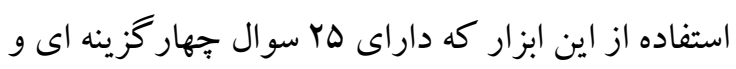

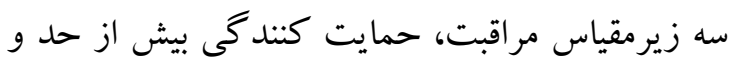

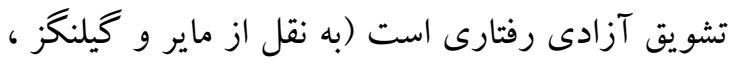

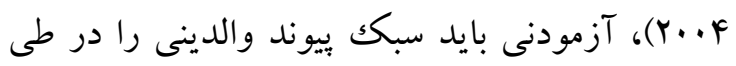

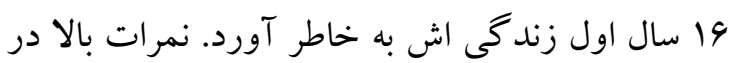

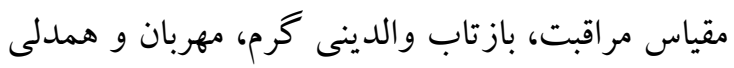
مى باشد. نمرات بايين در مقياس مراقبت، بازتاب

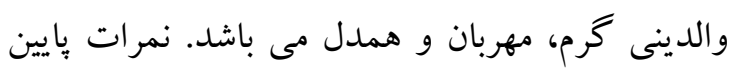

\footnotetext{
1 . Parental Bonding Instrument
} .Parker G.

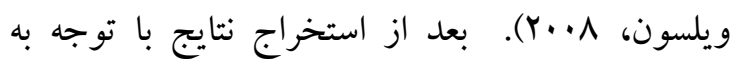
برقرار بودن شرط آزمون هاى بِارامتريك از بآماره

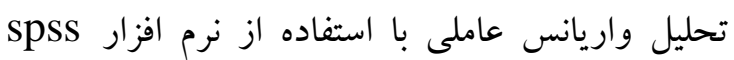
استفاده كرديد. جامعه آمارى بثزوهش شامل بيماران داراى اختلال خوردن مراجعه كننده به مراكز روانيزشكى، روان درمانى بالينى و مراكز درمانى جاقى و لاغرى شهر تهران كه از نظر سنى بين 19 تا سب سال است. روش

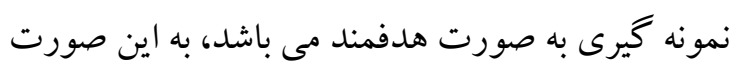

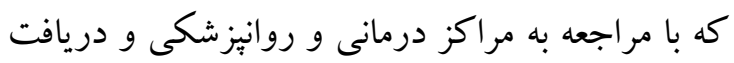
يرونده بيماران، افرادى كه داراى اختلال براشتهايى عصبى بودند و با توجه به تشخيص روانيزشك بر بر برك حسب ويراست ينجم راهنماى تشخيصى آمارى اختلالات روانى، علائم اختلال در آنها مشخص شد و

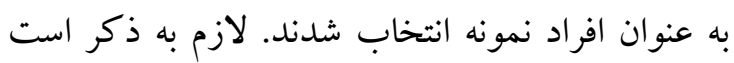

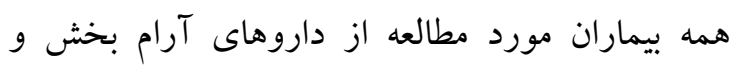
داروهاى خانواده SSRI و SSRI علائم اختلال استفاده مى كردند.

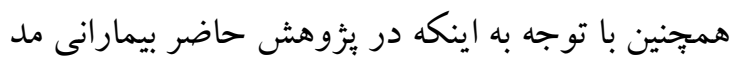

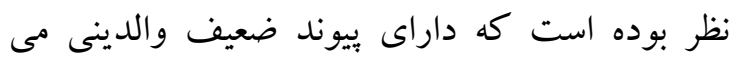
باشند ابتدا آزمودنى ها پس از اينكه تشخصى اختلال

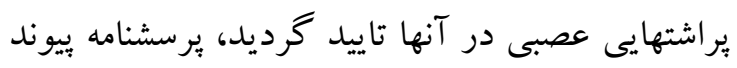
والدينى را تكميل كردند و آزمودنى هايى كه داراى بيوند ضعيف والدين (مراقبت كم و كنترل كننده بيش

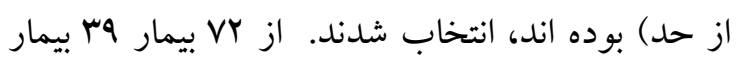

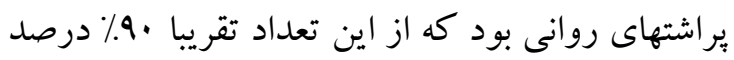

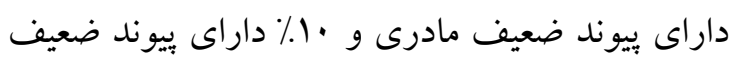
بدرى و مادرى بودند، به همين منظور در بزّوهش

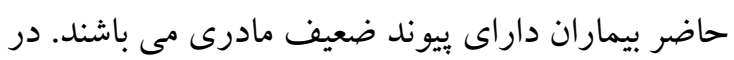

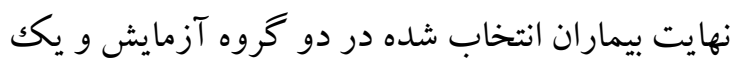

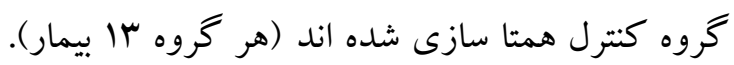
لازم به ذكر است، سه گروه از نظر معيار هاى ورودى 
باورهاى ذكر شده، بيانكر استفاده بيشتر فرد از باورها و

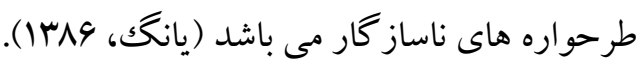

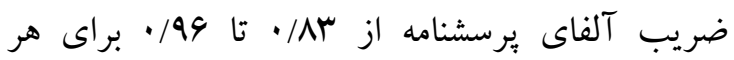

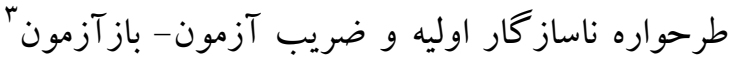
در جمعيت غيربالينى بين •ه/· تا rA/· به دست آمده است (شايقيان، •وب1). در اين تحقيق، پايايى يرسشنامه محاسبه گرديد نتايج نشان داد كل برسشنامه داراى

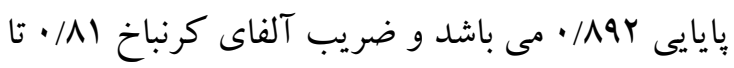

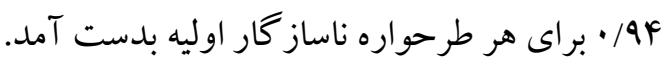

\section{يافته ها}

براى تجزيه و تحليل اطلاعات از آمار توصيفى(ميانخين

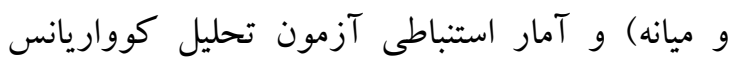
عاملى استفاده شد. نتايج توصيف ويز كى هاى دمو گرافى در جدول ا نمايش داده شده است.
در مقياس مراقبت، نشانگر والدينى سرد و طرد كننده و بى توجه است. نمرات بالا در مقياس حمايت كنند

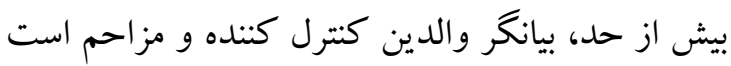
كه تمايل دارند كود كشان هميشه بجهه بماند. از سوى ديخر، نمرات بايين در مقياس حمايت كنندگى بيش از حد، منعكس كننده ى والدينى است كه به كودكى آزادى مى دهند و اسباب استقلال آنها را فراهم مى

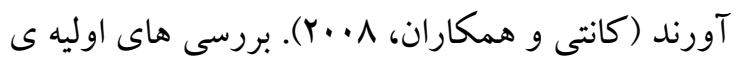

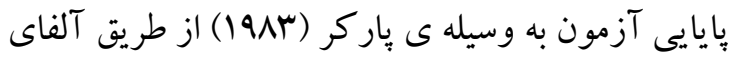

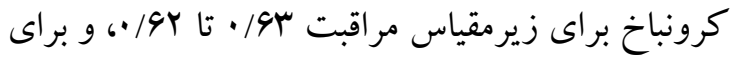

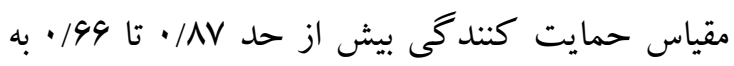
دست آمد. نمرات بالا در بعد حمايت كنندگى بيش از حد و نمرات بايين در بعد مراقبت به بييوند مشكل دار

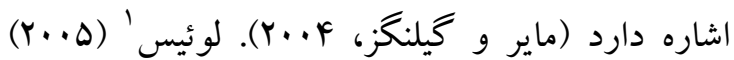
هايايى آزمون را از طريق آلفاى كرونباخ براى زيرمقياس مراقبت بr/4. و براى زيرمقياس حمايت كنندگى بيش از حد AV/· به دست آورد (ياركر،

.$(1914$

فرم كوتاه يرسشنامه بى طرحواره هاى يانتك ب. اين ابزار

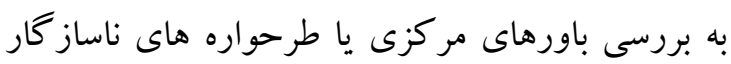

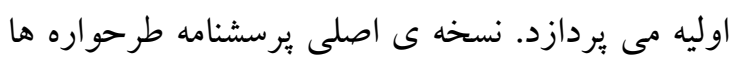

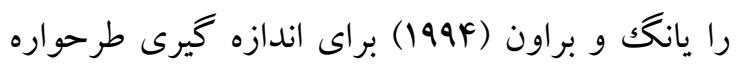

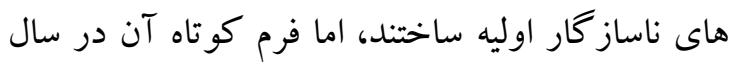

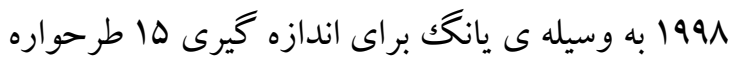

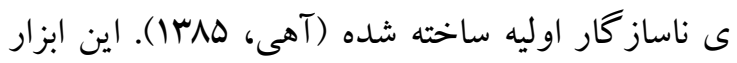

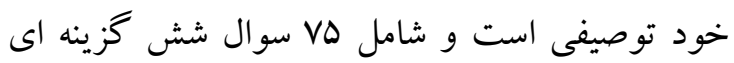
مى باشد. نمره كذارى اين برسشنامه از "يكك)" (ادرمورد من كاملاً نادرست است)) تا شش ((ادر مورد من كاملاً

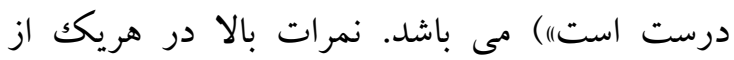




\begin{tabular}{|c|c|c|c|c|c|}
\hline \multicolumn{6}{|c|}{ جدول ا توصيف آمارى متغيرهاى دمو كرافى (n BN=39) } \\
\hline 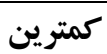 & 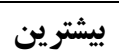 & انحر اف معيار & 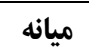 & ميانغين & \\
\hline 19 & rr & $1 / \Delta \Delta$ & M/D. & $|1 / 9|$ & 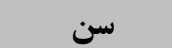 \\
\hline$r V / \cdot r$ & $\mu F / \Delta \Delta$ & $1 / \Delta \Lambda$ & $r \cdot / 4 q$ & r./Aq & 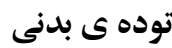 \\
\hline
\end{tabular}

خود كردانى و عملكرد مختل (Box s M=9N/9D)

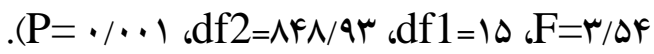

محدوديت هاى مختل ( Box S M=r/rY)

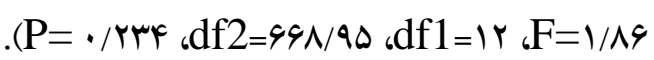
ديخر جهت مندى (B) (Box s M=19/\%)،

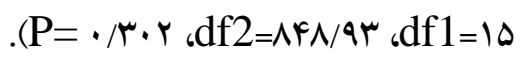
كوش به زنغى و بازدارى (Box s M=IV/aV)

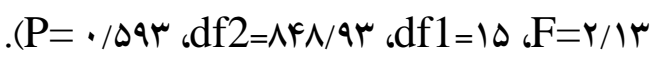
همجنين همخنى واريانس ها نيز با استفاده از آزمون

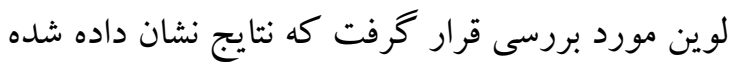

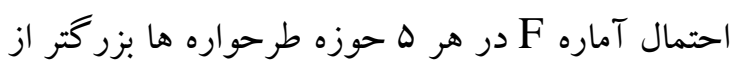
هـ/ است به عبارتى در همه حوزه هاى طرحواره

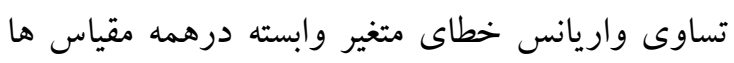

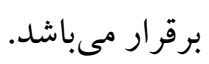

منطبق با جدول ا توصيف آمارى سن و توده بدنى بيماران نمايش داده شده است. ميانكين سن بيماران

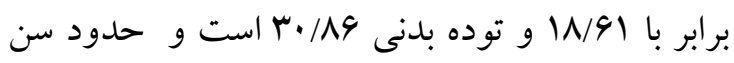

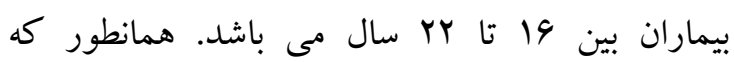

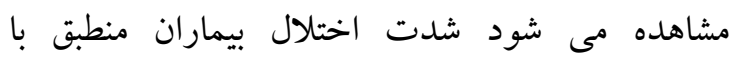
DSM-5 در بخش استنباط آمارى از آزمون كوواريانس عاملى بالى

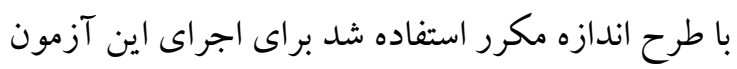

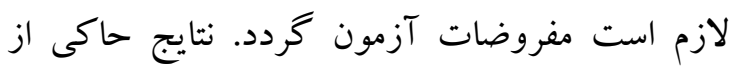
برقرار بودن مفروضات و تشخيص شاخص هاى آمارى بوده است. همكنى ماتريس كوواريانس با استفاده از

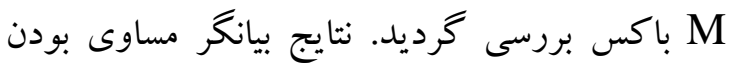
ماتريسهاى كواريانس مشاهدهده متغيرهاى وابسته (حوزه بريدگى و طرد، حوزه محدوديت هاى مختل،

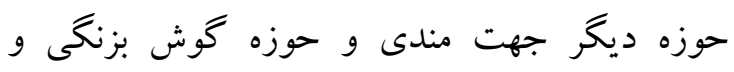

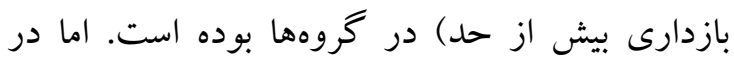

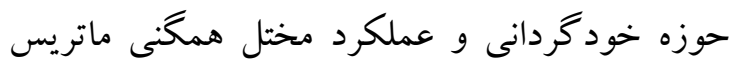
كوواريانس برقرار نيست، باتوجه به نتايج بدست آمدهد

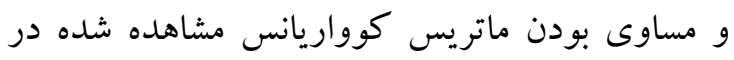
تحليل واريانس حند متغيره براى متغيرهاى كه شرط همسانى دارند شاخص لانداى ويلكز' و براى متغيرى

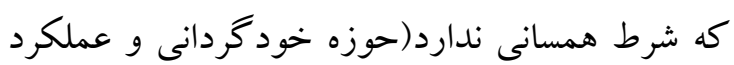

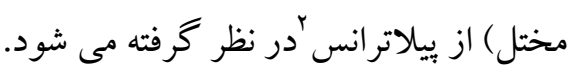

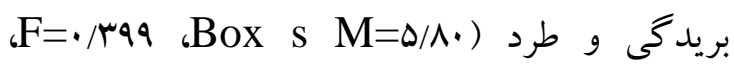
.$(\mathrm{P}=\cdot / 990$ d df2=19r $/ 90$ d df1=Ir 


\begin{tabular}{|c|c|c|c|c|c|c|c|}
\hline ضريب اتا & معنادارى سطح & فراوانى & مجذانغين & درجا آزى & مجذوروات & منبع تغييرات & طرحواره حوزه \\
\hline . TrT & 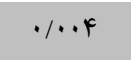 & $9 / 9 Y$ & $\Delta / \cdot r$ & 1 & $\Delta / \cdot r$ & ييش آزمون & \multirow{5}{*}{ بردى و } \\
\hline.$/ 1 r q$ & $\cdot / \cdot r V$ & $F / V Y$ & $r / r q$ & 1 & $r / r q$ & بيوند & \\
\hline.$/ 911$ & $\cdot / \cdots 1$ & $19 \pi / F V$ & $\wedge r / Q \varphi$ & r & $190 / 9$ & كروه & \\
\hline . ITFV &.$/ \cdot 11$ & D/ & $r / 90$ & r & $\Delta / \mu$ & گروهو ييوند & \\
\hline- & - & - & $\cdot / 0 \cdot V$ & rr & $19 / T F$ & خطا & \\
\hline$\cdot / Y 19$ & .104 & N/Ar & $F / \wedge q$ & 1 & $F / \wedge q$ & ييش آزمون & \multirow{5}{*}{ خود عمردانى } \\
\hline . rar &.$/ \cdot 1$ & $r \cdot 191$ & $11 / 49$ & 1 & $11 / 49$ & بيوند & \\
\hline ./NAY &.$/ \cdot 1$ & $|r r / r|$ & VY/AG & r & $\mid F \Delta / V$ & كروه & \\
\hline$\cdot /$ TAQ & 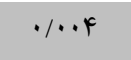 & $9 / 01$ & $r / \Delta q$ & r & $\mathrm{V} / \mathrm{A} \mathrm{A}$ & كروهو و ييوند & \\
\hline- & - & - & $\cdot / \Delta \Delta 1$ & rr & IV/ar & خطا & \\
\hline .1949 &.$/ . \cdot 1$ & $\Delta \Lambda / F Y$ & rV/VA & 1 & rV/VA & ييش آزمون & \multirow{5}{*}{ هاى مخدوديت } \\
\hline.$/ \cdot F F$ & . TMG & $1 / 49$ & .1994 & 1 & .1994 & بيوند & \\
\hline$\cdot / 119$ &.$/ \cdot 1$ & $V Y / \Delta I$ & $M F / F A$ & r & $9 N / 9 V$ & كروه & \\
\hline.$/ 1 \ldots$ & $\cdot / \Lambda \wedge \vee$ & $1 / V 9$ & - $|A F|$ & r & $1 / 91$ & گروهو وييوند & \\
\hline - & - & - & ./FVG & rr & $|\Delta / Y|$ & خطا & \\
\hline .1994 &.$/ \cdots 1$ & VI/VD & rr/Tr & 1 & rr/r & ييش آزمون & \multirow{5}{*}{ ديگر جهت } \\
\hline . IFr & $\cdot / \cdot Y \Lambda$ & $\Delta / Y \Lambda$ & $|/ N|$ & 1 & I/VY & ييوند & \\
\hline$\cdot / M N V$ & $\cdot / \cdot 1$ & $\mid r \Delta / \cdot 1$ & $F \cdot 194$ & r & $11 / 49$ & كروه & \\
\hline.$/ 499$ & $\cdot / \cdot v$ & $\Delta / \wedge q$ & $1 / 9 r$ & r & r/Ar & كروه و بيوند & \\
\hline- & - & - & •/TYO & rr & $1 \cdot / 4$ & خطا & \\
\hline . /ARV &.$/ \cdot 1$ & YF/VQ & rN/rA & 1 & YA/rA & ييش آزمون & \multirow{5}{*}{ 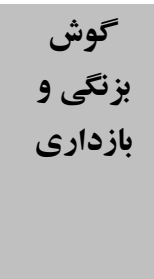 } \\
\hline$\% r$ & $\cdot|A Y|$ &.$/ \Delta r$ & .1 .4 & 1 & .1 .4 & بيوند & \\
\hline - /VAV &.$/ \cdot 1$ & $\Delta q / \cdot \vee$ & $9 V / 9 r$ & r & $\mid r \Delta / r V$ & كروه & \\
\hline .1 .94 & . MFV & $1 / .9$ & $1 / r \Delta$ & r & $r / \Delta$. & گروه و بيوند & \\
\hline - & - & - & $1 / 1 F$ & rr & rq/9r & خطا & \\
\hline
\end{tabular}

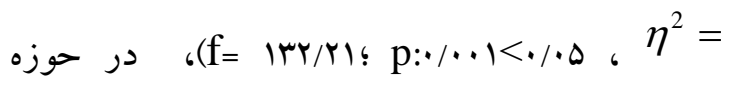
6 partial $\eta^{2}=$ محدوديت هاى مختل (1/9) 的 p: ؛

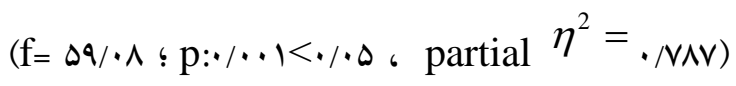
معنادار مى باشد. منطبق با نتايج حاصل شده در همه مولفه ها بين كروهها تفاوت وجود دارد بنابراين براى
همانطور كه مشاهده مى شود در همه حوزه ها متغير تصادفى كمكى (يش آزمون) معنادار است، يعنى بيش آزمون به طور معنادارى با متغير وابسته رابطه دارد. در رديف سوم جدول فوق براى همه حوزه ها اثر گروه نشان داده شده است، بِ از از تعديل نمرات بيش آزمودن، اثر معنى دار عامل بين آزمودنى هاى كروه وجود داشته است، بدين صورت كه در بريدكى و طرد

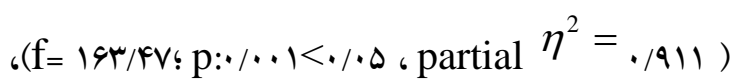

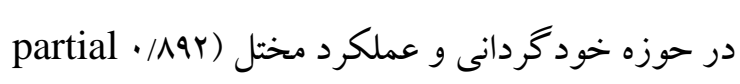


بررسى اثر گروههاى درمانى از آزمون تعقيبى بنفرنى استفاده شد كه نتايج آن در جدول Y بيان شده است.

\begin{tabular}{|c|c|c|c|c|c|}
\hline \multirow[t]{2}{*}{ سطح معنادارى } & \multirow{2}{*}{ ميانكين ها تفاوت } & \multicolumn{2}{|c|}{ كروه ها(درمان) } & \multirow[t]{2}{*}{ ميانكين } & \multirow{2}{*}{ طرحواره حوزه } \\
\hline & & $\mathbf{J}$ & I & & \\
\hline$\cdot / \cdot \cdot 1$ & $r / V \wedge$ 米 & طرحواره & شناختى -رفتارى & $19 / 4 \pi$ & \multirow{4}{*}{ 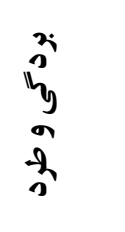 } \\
\hline$\cdot / \cdot \cdot 1$ & $-Y / V \wedge *$ & شناختى -رفتارى & طرحواره درمانى & $19 / 90$ & \\
\hline & & شناختى -رفتارى & \multirow[t]{2}{*}{ كنترل } & \multirow[t]{2}{*}{$r \cdot / r V$} & \\
\hline.$/ \cdot 1$ & $r / 9 Y$ 米 & طرحواره درمانى & & & \\
\hline.$/ \cdot 1$ & $1 / 90 *$ & طرحواره & شناختى -رفتارى & $191 \cdot V$ & \multirow{4}{*}{ 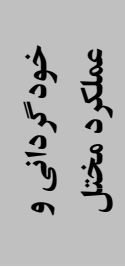 } \\
\hline $1 . .1$ & $-1 / 90 *$ & شناختى -رفتارى & طرحواره درمانى & $|f / F|$ & \\
\hline$\cdot / \cdots 1$ & $1 / M_{*} *$ & شناختى -رفتارى & \multirow[t]{2}{*}{ كنترل } & \multirow[t]{2}{*}{ IV/4D } & \\
\hline.$/ \cdot \cdot 1$ & $r / \Delta F_{*}$ & طرحواره درمانى & & & \\
\hline$\cdot / \cdot \cdot 1$ & $1 / 9 r^{*}$ & طرحواره درمانى & شناختى -رفتارى & $\mid \Delta / \cdot \Delta$ & \multirow{4}{*}{ 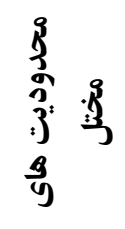 } \\
\hline$\cdot / \cdots 1$ & $-1 / 94$ & شناختى -رفتارى & طرحواره درمانى & $1 r / T r$ & \\
\hline$\cdot|| f \mid$ & • ( & شناختى -ر فتارى & \multirow[t]{2}{*}{ كنترل } & \multirow[t]{2}{*}{$10 / \Gamma \Lambda$} & \\
\hline$\cdot / \cdots 1$ & $r / r \Delta$ & طرحواره درمانى & & & \\
\hline$\cdot / \cdots 1$ & $r / 1$ * & طرحواره درمانى & شناختى -رفتارى & $19 / T^{\prime}$ & \multirow{4}{*}{ 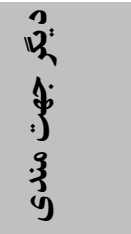 } \\
\hline.$/ \cdots 1$ & $-Y / I 1 *$ & شناختى -رفتارى & طرحو اره درمانى & $\mid F / I Y$ & \\
\hline$\cdot / \cdot \wedge$ & - RYS & شناختى -رفتارى & \multirow[t]{2}{*}{ كنترل } & \multirow[t]{2}{*}{$19 / 09$} & \\
\hline$\cdot / \cdots 1$ & $r / F Y_{*}$ & طرحواره درمانى & & & \\
\hline$\cdot / \cdots 1$ & $1 / \wedge 9 \%$ & طرحواره درمانى & شناختى -رفتارى & $1 D / A F$ & \multirow{4}{*}{ 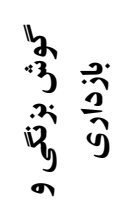 } \\
\hline.$/ \cdot 1$ & $-1 / \wedge 9 *$ & شناختى -رفتارى & طرحواره درمانى & $1 r / q F$ & \\
\hline.$/ \cdot 1$ & $1 / \Delta F_{*}$ & شناختى -رفتارى & كنترل & $\mid V / r \Lambda$ & \\
\hline$\cdot / \cdot \cdot 1$ & $r / \kappa \mu_{*}$ & طرحواره درمانى & & & \\
\hline
\end{tabular}

طورى كه طرحواره درمانى داراى اثر بخشى بالاترى

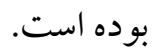

در خودگردانى و عملكرد مختل و گوش بزنگى و و بازدارى هم طرحواره درمانى و هم درمان شناختى

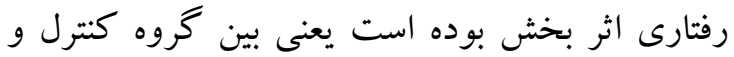

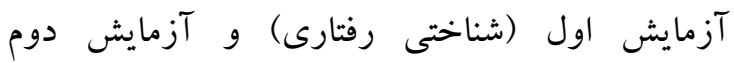

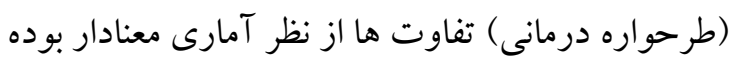
است، همجينين بين گروه آزمايش اول (طرحواره درمانى) و آزمايش دوم (شناختى رفتارى) ميزان تفاوت ها معنادار بوده است به طورى كه طرحواره درمانى داراى اثر بخشى بالاترى بوده است.
در آزمون بنفرنى، فرض صفر به عدم اختلاف بين كروه كنترل و آزمايش كفته مى شود و فرض خرص خلاف اختلاف بين گروه كنترل و آزمايش و اختلاف بين

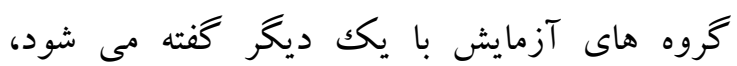
همانطور كه مشاهده مى شود، در حوزه بريدگى و وسى طرد، محدوديت هاى مختل و ديخر جهت مندى فقط طرحواره درمانى اثر بخش بوده است يعنى بين گروه كنترل و آزمايش دوم (طرحواره درمانى) تفاوت ها از نظر آمارى معنادار بوده است، همجِين بين گروه

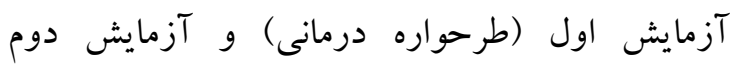
(شناختى رفتارى) ميزان تفاوت ها معنادار بوده است به 
جدول ^ آزمون مقايسه زوجى مربوط به ماند ارىى اثر بخشى درمان با توجه به ييوند والدينى

\begin{tabular}{|c|c|c|c|c|c|c|c|c|c|c|c|}
\hline \multicolumn{2}{|c|}{ كوش به زنكى } & \multicolumn{2}{|c|}{ ديكر جهت مندى } & \multicolumn{2}{|c|}{ محدوديت هاى } & \multicolumn{2}{|c|}{ خود كردانى } & \multicolumn{2}{|c|}{ بريدكى و طرد } & \multicolumn{2}{|l|}{ متغير } \\
\hline بيخيرى & مداخله & يبيخيرى & مل مداخله & يِيرى & مداخله & ييگيرى & مداخله & بيخيرى & مداخله & زمان & \\
\hline $19 / .9$ & $10 / \Delta V$ & $19 / 90$ & $10 / 9 V$ & $|\Delta / F|$ & $|F / V|$ & $10 / 91$ & $19 / 19$ & $19 / 19$ & $11 / 9 \Delta$ & مراقبت كم & درمان \\
\hline $19 /$. & $10 / 9 \Lambda$ & $19 / 4 r$ & $10 / 19$ & $10 / 1 T$ & $1 F / 94$ & $19 / 94$ & $10 / N \mid$ & $19 / v 9$ & $19 / 1 r$ & بيش حمايتخر & شناختى \\
\hline 191.0 & $10 / \Delta r$ & $19 / 0 r$ & $10 / 94$ & $1 \Delta / Y V$ & IF/Ar & $19 / Y V$ & $10 / 9 \Delta$ & $19 / A r$ & $19 / \cdot r$ & كل & رفتارى \\
\hline $\mid F / A$. & $1 r / 94$ & $\mid F / F r$ & $\mid F / A$ & IH/AF & $1 r / \cdot F$ & $10 / 99$ & $I F / F Y$ & $I V / r V$ & $1 \mathrm{~V} / \cdot 9$ & مراقبت كم & طرحواره \\
\hline $\mid r / F \Delta$ & $I r / A V$ & $1 r / 11$ & $\mid F / \cdot \Lambda$ & $|r / \Delta|$ & $\mid r / \cdot \Lambda$ & $1 \% / r$. & $1 \% / 99$ & $10 / 91$ & $19 / 0$ & بيش حمايتخر & درمانى \\
\hline $\mid F / I r$ & $I r / v \Delta$ & $|r / \Lambda|$ & $\mid F / F F$ & $\mid r / 1 \Lambda$ & $15 / .9$ & $\mid F / 94$ & $18 / 19$ & $19 / 49$ & $19 / 1$. & كل & \\
\hline $10 / .9$ & $\mid F / 94$ & $10 / I V$ & $10 / 19$ & $\mid F / Y r$ & $1 r / 9 F$ & $10 / 4 \theta$ & $10 / \cdot V$ & $11 / 19$ & IV/aY & مجموع & \\
\hline $\begin{array}{l}-. / \text { IVE } \\
. / \mathrm{Yr}\end{array}$ & - & $\begin{array}{l}\cdot / T M \Lambda \\
\cdot / \cdot \Lambda V\end{array}$ & - & $\begin{array}{l}-. / 1 F Y \\
. / 109\end{array}$ & - & $\begin{array}{l}-\cdot / r \mu \cdot * \\
\cdot / \cdot F F\end{array}$ & - & 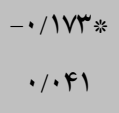 & - & ز مداخله & بعد \\
\hline- & $\begin{array}{l}. \text { IVG } \\
. / \mathrm{rr}\end{array}$ & - & $\begin{array}{l}-\cdot / Y \mu \wedge \\
\cdot / \cdot A V\end{array}$ & - & $\begin{array}{l}. / 1 F Y \\
. / 1 D G\end{array}$ & - & $\begin{array}{l}\cdot / r \mu \cdot * \\
\cdot / \cdot F F\end{array}$ & - & $\begin{array}{l}\cdot / \mid V r_{*}^{*} \\
\cdot / \cdot \varphi l\end{array}$ & بعيرى & \\
\hline
\end{tabular}

در طرحواره هاى حوزه بريدگى و طرد (نقص و شرم، رها شدگى، محروميت هيجانى و انزواى اجتماعى) و خود گردانى و عملكرد مختل (بى كفايتى، گرفتار و و شكست) بيشترين آسيب و در سايرحوزه ها (محدوديت هاى مختل،ديكر جهت مندى و حوزه گوش بزنكى بيش ازحد) به نسبت آسيب كمترى دارند. نتيجه بدست آمده همراستا با بزوهش والر و

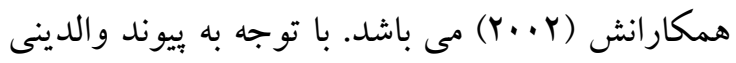
نيز نشان داده شد در حوزه بريدگى و طرد، خودگر دانى و عملكرد مختل و ديكرجهت مندى، نقش بيوند والدينى در مداخله اثر بخش بوده است و بيماران داراى بيوند والدينى بيش حمايت گر نسبت به مراقبت كم، درمان طرحواره در آنها اثر بخشى بالاترى داشته است اما درمان شناختى رفتارى تحت تاثير بيوند والدينى قرار نكرفته است. از يزّوهش هاى هم راستا به بزّوهش،

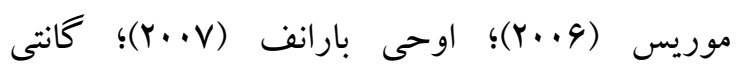

$$
\text { (Y) }
$$

همجينين منطبق با نتايج حاصل شده، در بررسى تعامل والد-كودكك اينگونه برداشت مى شود، در بيمارانى
جدول F F مربوط به آزمون بنفورنى در خصوص، ماند كارى اثر بخشى درمان شناختى رفتارى و طرحواره درمانى در بيماران يراشتهاى روانى با توجه به بيوند والدينى مى باشد، نتايج نشان مى دهد در حوزه بردگى و طرد در بيماران داراى بيوند والدينى بيش حمايت گرى، طرحواره درمانى داراى ماند گارى بيشترى بوده است، در حوزه خود گردانى و عملكرد مختل طرحواره درمانى و درمان شناختى رفتارى در بيماران داراى بيوند والدينى بيش حمايت گرى داراى ماندگارى بيشترى بوده است، در حوزه محدوديت هاى مختل و كوش بزنگى و ديخر جهت مندى طرحواره درمانى بدون نقش بيوند والدينى داراى اثر بخشى بالاترى بوده است. هدف مطالعه حاضر مقايسه اثربخشى دو روش درمانى (طرحواره درمانى و درمان شناختى رفتارى) بر بهبود طرحواره هاى ناساز گار اوليه در بيماران براشتهاى عصبى با توجه به بيوند والدينى بوده است. يافته هاى حاصل از تحليل نتايج نشان داده اين گروه از بيماران 
موقعيت ها و رفتارهاى اضطراب زا اجتناب مى كنند،

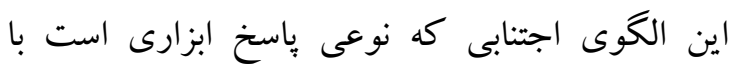
كاهش عواطف منفى، تقويت مى شود. هيجان هاى

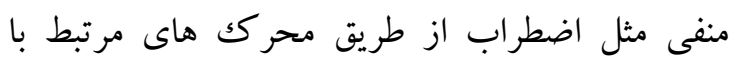
خاطرات دوران كودكى، برانخيخته مى شوند و بيمار براى اجتناب از اين محر كك ها، سعى مى كند، هيجان هاى منفى را تجربه نكند، از آنجا كه اين اجتناب در طى زمان به صورت عادت در مى آيند، بنابراين تغيير

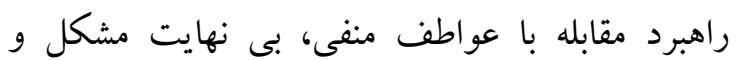
طاقت فرسا مى شود در نتيجه طرحواره درمانى از آنجا كه رويكردى يكهارجه است و تركيبى از درمان

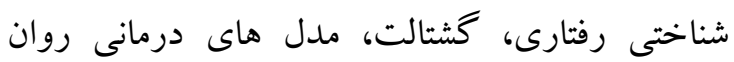
يويشى و بين فردى است و تاثير قابل توجهى بر روابط درمانى، هيجانات و تجارب اوليه زندگى (يانگك و

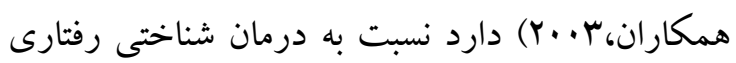
براى اين گروه از بيماران اثر بخشى بالاترى دارد. از

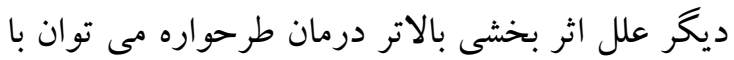

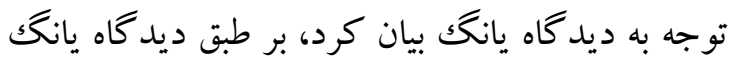
(Y.r.r) مصرف غذا به عنوان روشى براى اجتناب از هيجانات منفى ناشى از آن منجر مى شود، در واقع رفتارهاى

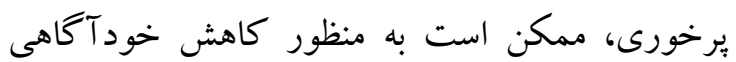
فرد نسبت به هيجانات غير قابل تحمل مربوط به الخوها

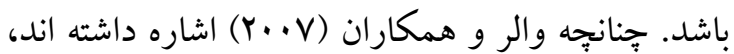
از طريق فر آيندهاى تداوم طرحواره مى توان اختلال يرخورى را تشخيص داد در نتيجه طرحواره درمانى مى تواند با اصلاح طرحواره هاى آسيب زا سيكل معيوبى كه منجر به تداوم طرحواره هاى ناساز گار مى شود را بشكند و باعث كاهش رفتارى مر تبط با خوردن شود. در انتها به درمانگران توصيه مى شود همانطور كه اثر بخشى درمان مهم مى باشد، ماندكارى درمان مهمتر و

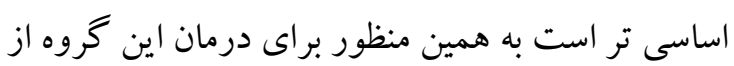

كه در حوزه خود گردانى و عملكرد مختل مشكل دارند، در روند رشد اوليه شان والدينشان براى رفا و آزايش آنها همه كار انجام داده اند و اجازه رشد

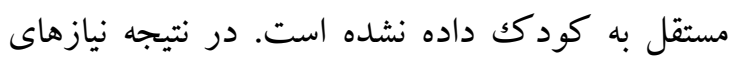
هيجانى كودكك به دليل در گيرى بيش از حد و الدين در مسائل كودكى به خودگردانى و محدوديت هاى واقع بينانه ارضا نخرديد است. در اين خصوص مى توان به

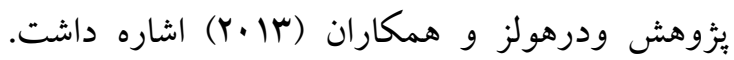
همجنين بيمارانى كه در حوزه بريدكى و طرد مشكل دارند نياز به امنيت در آنها بر آورده نشده است و آنها جيزى تحت عنوان ثبات هيجانى از جانب مادر دريافت نكرده اند. هم راستا با نتيجه بدست آمده مى تو توان اشاره

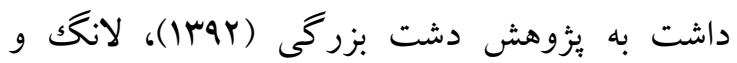

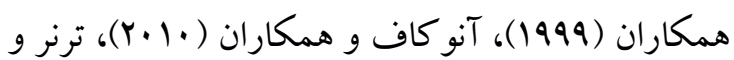

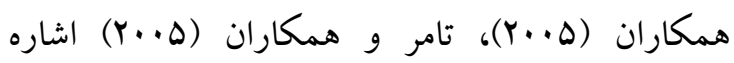
داشت.

\section{نتيجه كيرى}

نتيجه بدست آمده اينكونه تبيين مى شود كه : مدل طرحواره نسبت به مدل شناختى رفتارى باعث اجتناب راحت تر بيمار از عواطف آسيب زاى مربوط به طرحواره مى شود. از آنجا كه در درمان شناختى رفتارى در ابتداى درمان از بيماران انتظار مى رود افكار و احساسات خود را مشاهده و ثبت كنند، ولى اين كروه از بيماران بدليل، شدت مشكلى كه دارند قادر به انجام اين تكاليف نيستند. همجِنين به نظر مى رسد شناخت واره ها و هيجان هاى اين گرووه از بيماران خارج از دسترس شان قرار دارد آنها تصاوير ذهنى و آشفته ساز خود را بلو كه مى كنند و نمى خو اهند ريشه مشكلات خود را بيابند، بيماران از طريق رفتارهاى جبران و اجتناب نظير رزيم گرفتن، روزه گرفتن و يا ورزش بيش از حد و برخورى/ باكسازى از بسيارى از 
European Eating Disorders Review,21(1), 45-51.

Cella S; Lannaccone M; Cotrufo P. (2014).

How perceived parental bonding affects self- coneptand drive for thinness : A community- based study. Eating Behaviors 25. 110-115.

Canetti, L., Kanyas, K., Lerer, B., Latzer, Y., \& Bachar, E. (2008). Anorexia nervosa and parental bonding: the contribution of parentgrandparent relationships to eating disorder psychopathology. Joumal of Clinical Psychology, 64(6), 703-716.

Cecero, J. J., \& Young, J. E. (2001). Case of Silvia: A schema-focused approach. Journal of Psychotherapy Integration, 11(2), 217-229.

Colman, A. M. (2015). A dictionary of psychology. Oxford University Press, USA.

Cooper, M. J., \& Young, E. (2016). Parental Bonding and Body Mass Index in a Female Community Sample: The Mediating Role of Eating Disorder Thoughts and Core Beliefs. Behavioural and cognitive psychotherapy, 44(01), 123-127.

Cooper, P. J., Whelan, E., Woolgar, M., Morrell, J., \& Murray, L. (2004). Association between childhood feeding problems and matemal eating disorder: role of the family environment. The British Joumal of Psychiatry, 184(3), 210-215.

Dalle Grave, R., Calugi, S., Sartirana, M., \& Fairbum, C. G. (2015). Transdiagnostic cognitive behaviour therapy for adolescents with an eating disorder who are not underweight. Behaviour research and therapy, 73, 79-82.

Dashtbozorgi, Z., Amiri, SH., Mazaheri A., \& Talebi, H. (2013). The effect of intervention on attachment to overeating and obesity in Girls (Unpublished Ph.D dissertation). Isfahan University. (In Persian)

Enten, R. S., \& Golan, M. (2009). Parenting styles and eating disorder pathology. Appetite, 52(3), 784-787.

Fairbum, C. G., Cooper, Z, Shafran, R., \& Wilson, G. T. (2008). Eating disorders: A trans diagnostic protocol.

Fairchild, H., \& Cooper, M. (2010). A multidimensional measure of core beliefs relevant to eating disorders: Preliminary

$$
\begin{aligned}
& \text { بيماران، رويكرد طرحواره درمانى را در جلسات بيشتر }
\end{aligned}
$$

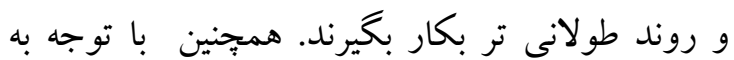

$$
\begin{aligned}
& \text { نقش بالاى بيوند والدينى در علل و تداوم براشتهاى } \\
& \text { عصبى توصيه مى شود به خانو اده ها آموزش هاى لازم } \\
& \text { در خصوص تاثير سبك دلبستخى اوليه كودكك در } \\
& \text { اختلالات بعدى رشد كودكان ارائه شود. يا توجه به } \\
& \text { اينكه نقص و شرم، بريدگى و طرد و ... از مهمترين } \\
& \text { عوامل تداوم اختلالهاى خوردن شناخته شده است به } \\
& \text { يزوهش كران آتى ييشنهاد مى شود در خصوص ارتباط } \\
& \text { بين آلكسى تايميا (يعنى دشوارىهاى شناسايى و تشريح } \\
& \text { هيجانها) و اختلالهاى خوردن يُزوهش انجام دهند، } \\
& \text { اميد است كه با انجام اين دسته از يزووهش ها بتوانيد به } \\
& \text { كمكى به جامعه يزشكى نماييم و گرهى از مشكلات }
\end{aligned}
$$

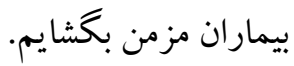

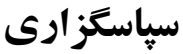

بدين وسيله از زحمات مسئولين مراكز درمانى بالاخص بيمارستان هاى روانيز شكى شهر تهران و از كمكك هاى

بى دريغ جناب دكتر محمد على همتى در تشخيص

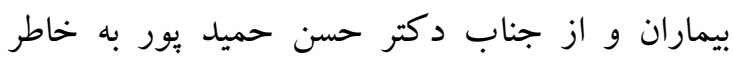
كمك ايشان در تدوين بروتكل طرحواره درمانى كمال تشكر و قدردانى دارم.

\section{Refrences}

Ahi, GH. (2006). Standardization of a short version of the Young Schema Questionnaire (Unpublished Master's Thesis). Allameh Tabatabaei University. (In Persian)

American Psychiatric Association. (2013). Diagnostic Manual for Psychiatric Disorders, Fifth Edition. (In Persian)

Boone, L., Braet, C., Vandereycken, W., \& Claes, L. (2013). Are maladaptive schema domains and perfectionism related to body image concems in eating disorder patients? 
development and validation. Eating behaviors, 11(4), 239-246.

Gunty, A. L., \& Buri, J. R. (2008). Parental Practices and the Development of Maladaptive Schemas. Online Submission.

Haines, J., Rifas-Shiman, S. L., Horton, N. J., Kleinman, K., Bauer, K. W., Davison, K. K. ... \& Gillman, M. W. (2016). Family functioning and quality of parent-adolescent relationship: cross-sectional associations with adolescent weight-related behaviors and weight status. Intemational Journal of Behavioral Nutrition and Physical Activity, 13(1), 1.

Jones, C. J., Leung, N., \& Harris, G. (2006). Father-daughter relationship and eating psychopathology: The mediating role of core beliefs. British Joumal of Clinical Psychology, 45(3), 319-330.

Krug, I, King, R. M., Youssef, G. J., Sorabji, A., Wertheim, E. H., Le Grange, D., ... \& Olsson, C. A. (2016). The effect of low parental warmth and low monitoring on disordered eating in mid-adolescence: Findings from the Australian Temperament Project. Appetite, 105, 232-241.

Lattimore, P. J., Wagner, H. L., \& Gowers, S. (2000). Conflict avoidance in anorexia nervosa: An observational study of mothers and daughters. European Eating Disorders Review, 8(5), 355-368.

Leahi, R. L. (2015). Cognitive-behavioral techniques for depression and anxiety disorders. (In Persian)

Leung, N., Waller, G., \& Thomas, G. (1999). Core beliefs in anorexic and bulimic women. The Journal of nervous and mental disease, 187(12), 736-741.

Lewis, J. A. (2005). Early maladaptive schemas and personality dysfunction in adolescence: An investigation of the moderating effects of coping styles. ETD Collection for Fordham University.

Lyke Jennifer, Masten Julie. (2013). Family functioning and risk foutors for disordered eating. Eating Behaviors 14. 497-499.

Mahmoudiandastnaee, T., Amini, SH., Neshat Hossein, H., \& Manshei, GH. (2015). The comparison of the effectiveness of schema therapy and cognitive-behavioral therapy on eating disorder symptoms in patients between the ages of 16-23 with bulimia Nervosa regarding parental bonding. Quarterly Joumal of Applied and Psychological Research, 6 (3), 169-186. (In Persian)

Meyer $\mathrm{C}$, Gillings $\mathrm{K}(\boldsymbol{P} \cdot \boldsymbol{r})$. Parental bonding and bulimic psychopathology: The mediating role of mistrust/abuse beliefs. Int $\mathbf{J}$ Eat Disord:35(2):229-33.

Muris, P. (2006). Maladaptive schemas in non-clinical adolescents: Relations to perceived parental rearing behaviours, big five personality factors and psychopathological symptoms. Clinical Psychology \& Psychotherapy, 13(6), 405413.

Murphy, R., Straebler, S., Cooper, Z, \& Fairbum, C. G. (2010). Cognitive behavioral therapy for eating disorders. Psychiatric Clinics of North America,33(3), 611-627.

Nicholls, D., \& Grindrod, C. (2013). Behavioural eating disorders. Paediatrics and Child Health, 23(1), 11-17.

Oei, T. P., \& Baranoff, J. (2007). Young Schema Questionnaire: Review of psychometric and measurement issues. Australian Journal of Psychology,59(2), 78-86.

Parker, G. (1983). Parental overprotection: A risk factor in psychosocial development. Grune \& Stratton.

Patrick, H., \& Nicklas, T. A. (2005). A review of family and social determinants of children's eating pattems and diet quality. Journal of the American College of Nutrition, 24(2), 8392.

Pugh, M. (2015). A narrative review of schemas and schema therapy outcomes in the eating disorders. Clinical psychology review, 39, 30-41.

Sadock, B. J., \& Sadock, V. A. (2008). Kaplan \& Sadock's concise textbook of clinical psychiatry. Lippincott Williams \& Wilkins.

Shayeghian, Z, Agilard Vafaei, M., \& Rasoulzadeh Tabatabaei, S.K. (2011). Study of schemas and parental bonding in normal, obese, or adolescent girls with symptoms of bulimia Nervosa. Scientific Joumal of Shahid Beheshti University of Medical Sciences, 16 (1), 30-38. (In Persian) 
Stice, E., Presnell, K., \& Spangler, D. (2002). Risk factors for binge eating onset in adolescent girls: a 2-year prospective investigation. Health Psychology, 21(2), 131.

Striegel-Moore, R. H., \& Bulik, C. M. (2007). Risk factors for eating disorders.American Psychologist, 62(3), 181.

Strober, M., \& Humphrey, L. L. (1987). Familial contributions to the etiology and course of anorexia nervosa and bulimia. Joumal of Consulting and Clinical Psychology, 55(5), 654.

Swanson, H., Power, K., Collin, P., Deas, S., Paterson, G., Grierson, D., ... \& Taylor, L. (2010). The relationship between parental bonding, social problem solving and eating pathology in an anorexic inpatient sample.European Eating Disorders Review, 18(1), $22-32$.

Tetley, A., Moghaddam, N. G., Dawson, D. L., \& Rennoldson, M. (2014). Parental bonding and eating disorders: A systematic review. Eating behaviors ,15(1), 49-59.

Thimm, J. C. (2010). Mediation of early maladaptive schemas between perceptions of parental rearing style and personality disorder symptoms.Joumal of behavior therapy and experimental psychiatry, 41(1), 52-59.

Turner, H. M., Rose, K. S., \& Cooper, M. J. (2005). Parental bonding and eating disorder symptoms in adolescents: The meditating role of core beliefs. Eating Behaviors, 6(2), 113-118.

Turner, H., Marshall, E., Stopa, L., \& Waller, G. (2015). Cognitive-behavioural therapy for outpatients with eating disorders: Effectiveness for a transdiagnostic group in a routine clinical setting. Behaviour research and therapy, 68, 70-75.

Unoka, Z., Tölgyes, T., Czobor, P., \& Simon, L. (2010). Eating disorder behavior and early maladaptive schemas in subgroups of eating disorders. The Joumal of nervous and mental disease, 198(6), 425-431.

Voderholzer, U., Schwartz, C., Thiel, N., Kuelz, A. K., Hartmann, A., Scheidt, C. E., ... \& Zeeck, A. (2013). A comparison of schemas, schema modes and childhood traumas in obsessive-compulsive disorder, chronic pain disorder and eating disorders. Psychopathology, 47(1), 24-31.

Waller, G., Kennerley, H., \& Ohanian, V. (2007). Schema-Focused Cognitive-Behavioral Therapy for Eating Disorders. Book Chapter Selected

Waller, G., Ohanian, V., Meyer, C., \& Osman, S. (2002). Cognitive content among bulimic women: The role of core beliefs. International Journal of Eating Disorders, 28(2), 235-241.

Wilson, G. T., Fairbum, C. C., Agras, W. S., Walsh, B. T., \& Kraemer, H. (2002). Cognitivebehavioral therapy for bulimia nervosa: Time course and mechanisms of change. Journal of consulting and clinical psychology, 70(2), 267.

Yang, C. (1999). Cognitive therapy for personal disorders: Schematic approach.

Young, J.E. (1994). Cognitive therapy for personality disorders: A schema-focused approach (rev. Professional Resource Press/Professional Resource Exchange.

Young, J. E., Klosko, J. S., \& Weishaar, M. E. (2003). Schema therapy: A practitioner's guide.. Joumal of psychosomatic research, 57,113-116. 